\title{
RESEARCH
}

Open Access

\section{Biomass and dominance of conservative species drive above-ground biomass productivity in a mediterranean-type forest of Chile}

Ariel Isaías Ayma-Romay* (i) and Horacio E. Bown

\begin{abstract}
Background: Forest productivity has a pivotal role in human well-being. Vegetation quantity, niche complementarity, mass-ratio, and soil resources are alternative/complementary ecological mechanisms driving productivity. One challenge in current forest management depends on identifying and manipulating these mechanisms to enhance productivity. This study assessed the extent to which these mechanisms control aboveground biomass productivity (AGBP) of a Chilean mediterranean-type matorral. AGBP measured as tree aboveground biomass changes over a 7-years period, was estimated for twelve $25 \mathrm{~m} \times 25 \mathrm{~m}$ plots across a wide range of matorral compositions and structures. Variables related to canopy structure, species and functional diversity, species and functional dominance, soil texture, soil water and soil nitrogen content were measured as surrogates of the four mechanisms proposed. Linear regression models were used to test the hypotheses. A multimodel inference based on the Akaike's information criterion was used to select the best models explaining AGBP and for identifying the relative importance of each mechanism.

Results: Vegetation quantity (tree density) and mass-ratio (relative biomass of Cryptocarya alba, a conservative species) were the strongest drivers increasing AGBP, while niche complementarity (richness species) and soil resources (sand, \%) had a smaller effect either decreasing or increasing AGBP, respectively. This study provides the first assessment of alternative mechanisms driving AGBP in mediterranean forests of Chile. There is strong evidence suggesting that the vegetation quantity and mass-ratio mechanisms are key drivers of AGBP, such as in other tropical and temperate forests. However, in contrast with other studies from mediterranean-type forests, our results show a negative effect of species diversity and a small effect of soil resources on AGBP.

Conclusion: AGBP in the Chilean matorral depends mainly on the vegetation quantity and mass-ratio mechanisms. The findings of this study have implications for matorral restoration and management for the production of timber and non-timber products and carbon sequestration.
\end{abstract}

Keywords: Above-ground biomass productivity, Diversity, Niche complementarity, Mass-ratio, Mediterranean, Soil resources

\footnotetext{
* Correspondence: ariel.isaias.aymar@ug.uchile.cl

Facultad de Ciencias Forestales y Conservación de la Naturaleza, Universidad de Chile, Avenida Santa Rosa, 11315 Santiago, Chile
} 


\section{Background}

The aboveground biomass productivity (AGBP) of the world's forests supports ecosystem functioning and key ecosystem services to human well-being (Chapin et al. 1997). At small-scales and under natural conditions AGBP is driven by vegetation quantity, species diversity, particular dominant species and soil resources availability through four so far controversial hypothesis, recently compared (Lohbeck et al. 2015; Finegan et al. 2015; Prado-Junior et al. 2016; Kamruzzaman et al. 2017; van der Sande et al. 2017a), and namely:

a) The hypothesis of vegetation quantity proposes that the amount of vegetation is the main driver of changes in the rates of different ecosystem processes (Lohbeck et al. 2015). Consistent with this hypothesis, some studies show that greater aboveground biomass, tree density, basal area and leaf area increase AGBP (Paquette and Messier 2011; Reich 2012; Prado-Junior et al. 2016). However, greater vegetation quantity also might reduce AGBP, due to competition for resources and mortality (Finegan et al. 2015). Thereby, forests with smaller biomass have shown be more productive than primeval forests (van der Sande et al. 2017a; Ojha and Dimov 2017).

b) The hypothesis of niche complementarity predicts that greater plant species diversity increases the rate of ecosystem processes maximizing resources use (water, nutrients), since different species use different resources, or the same resources, but with spatial and temporal variations (Tilman 1997). Then, it is expected that forest AGBP increase with a greater number of tree species (richness) and evenness (Zhang et al. 2012), as well as with higher functional diversity (Paquette and Messier 2011). However, other studies show neutral or negative effects of these variables on AGBP (Finegan et al. 2015; Prado-Junior et al. 2016; van der Sande et al. 2017a).

c) The hypothesis of mass-ratio proposes that the extent to which species affect ecosystem processes are proportional to their contribution to the total plant biomass (Grime 1998). Then, highly productive dominant species (species with greater biomass) with particular traits may drive forest AGBP (RuizJaen and Potvin 2010; Finegan et al. 2015; PradoJunior et al. 2016). However, some studies showed that dominance had little effect on forest AGBP, compared with the effect of the species diversity and vegetation quantity (Lohbeck 2015; van der Sande et al. 2017a).

d) The belowground resource availability (here coined as a hypothesis) predicts that soil resource availability is a key factor limiting ecosystem processes (Chapin et al. 2014; van der Sande et al. 2017b). Thereby, greater soil nitrogen (Campo and Vázquez-Yánes 2004) and/or soil water contents may increase AGBP (Sala et al. 1988; Poorter et al. 2017). However, low levels of resources available in forest soils do not always translate into reduced AGBP (Prado-Junior et al. 2016), as tree species develop adaptations allowing them to grow in conditions limited by resources (Wright et al. 2011).

The relative importance of these mechanisms changes with the environmental context and forest composition, and their influences are not always clear (Díaz et al. 2007). Therefore, one of the greatest challenges in current forest management and climate change mitigation depends on correctly identifying and manipulating the drivers to maintain or even enhance forest productivity (van der Sande et al. 2017a). However, there is uncertainty about the effects of these mechanisms working simultaneously on forest productivity.

Mediterranean-type climate ecosystems occupy 5\% of the terrestrial surface of the world while holding $20 \%$ of the global plant diversity (Rundel et al. 2016). The matorral is a typical mediterranean-type forest of central Chile composed by evergreen sclerophyllous and deciduous malacophyllous plant species. The matorral is distributed across highly variable environmental conditions (topography, altitude) and exposed to permanent human disturbances (deforestation, fire, and livestock raising) (Rundel et al. 2016),- which in turn have modified the vegetation quantity (Bown et al. 2014), soil resources (Mooney and Dunn 1970), diversity and composition (Rundel 1981). The consequences of these changes in aboveground biomass productivity (AGBP) have been scarcely evaluated (Fuentes et al. 1995).

In line with the hypothesis of vegetation quantity, AGBP in the matorral migth increase with higher tree density, as it reduces environmental stresses, such as high radiation, high soil evaporation and soil erosion (Mooney and Dunn 1970). Besides, according to the hypothesis of soil resources availability, AGBP in the matorral might increase with increasing soil nitrogen (Kummerow et al. 1982) and soil water contents (Rodríguez-Soalleiro et al. 2018; Meza et al. 2018), since soil nutrients and water deficiencies are common factors limiting the growth of mediterranean-type forests (Mooney and Dunn 1970).

The effect of niche complementarity on Chilean matorral AGBP has not been evaluated before. However, the AGBP might increase with high species and functional diversity, as in previous studies carried out in the Mediterranean Basin (Vilà et al. 2003, 2007, 2013; RuizBenito et al. 2014). Niche complementarity in the 
matorral might be expected, since deciduous malacophyllous and evergreen sclerophyllous species can use the soil water from different soil depths and grow in dissimilar seasons of the year, promoting spatial and temporal niche differentiation (Giliberto and Stay 1978; Montenegro et al. 1982a; Canadell and Zedler 1995). However, in line with the mass-ratio mechanism, the AGBP of the matorral might also increase in communities dominated by evergreen sclerophyllous species with a conservative strategy (sensu Reich 2012), such as was observed in the Mediterranean Basin (Ruiz-Benito et al. 2014). These conservative species are characterized by longer leaf life span and higher plant height (Canadell and Zedler 1995). Such attributes may allow them to uptake carbon continuously over the year (Mooney 1977), with a greater competitive advantage for light acquisition compared to deciduous malacophyllous species (Armesto et al. 1994).

The aim of this study was to evaluate how alternative/ complementary mechanisms based on the previously described hypotheses of vegetation quantity, niche complementarity, mass-ratio, and soil resources availability explain the AGBP of the Chilean matorral.

\section{Methods}

\section{Study area}

The study area is located in the National Reserve "Roble-

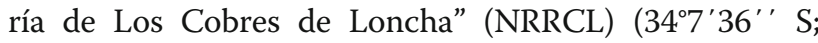
$71^{\circ} 11^{\prime} 18^{\prime \prime}$ W), Commune of Alhué, Metropolitan Region, Chile. Cold, wet winters (May-September) and dry, warm summers (October-April) characterize this part of Central Chile as a mediterranean region (Hajek and di Castri 1975). This region has a temperate and sub-humid climate, with an average annual air temperature of $14.7^{\circ} \mathrm{C}$ and average annual precipitation of $474 \mathrm{~mm}$ (Amigo and Ramírez 1998). This typical Chilean matorral has high variability in composition and structure due to high environmental heterogeneity and historic human disturbances (Rundel et al. 2016). The vegetation in the NRRCL is described as "sclerophyllous woodlands of the Coastal mountain range". This type of vegetation has been disturbed mainly by fire, cattle grazing and firewood extraction, which have formed different types of vegetation in a range from evergreen sclerophyllous woodlands to deciduous malacophyllous scrublands (Gajardo 1994). These types are distributed in medium altitudes (300 to $1200 \mathrm{~m}$ a.s.l.) in moderate slopes. The

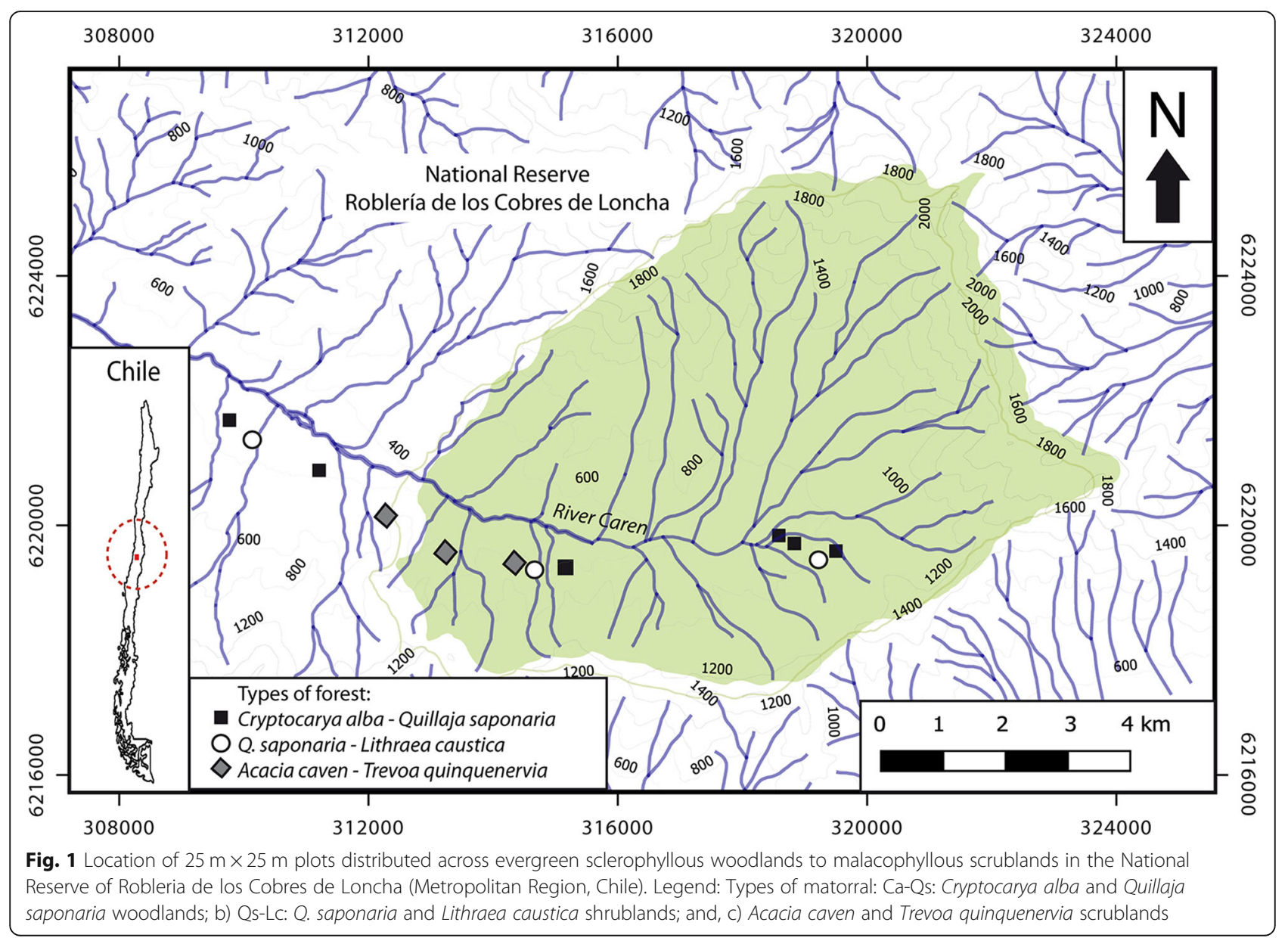


soil is derived from granitic and colluvial origin. The soil textures are loams, with a presence of quartz and gravel (Bown et al. 2014).

In 2010 twelve plots of $25 \mathrm{~m} \times 25 \mathrm{~m}$ were established (Fig. 1). These plots were distributed in different types of matorral with broad variation in structure, species diversity, composition and soil resources availability across sclerophyllous woodlands and malacophyllous shrublands. Historic human disturbance is the key factor explaining such differences across the matorral (Armesto and Martínez 1978; Rundel 1981). The plots were distributed in a small altitudinal range from 300 to $800 \mathrm{~m}$ within a similar lower northern aspect slope extending for $13 \mathrm{~km}$. The effect of the altitude upon the AGBP of the matorral was not evaluated into this study, because we assumed that differences in vegetation and soil resources were not explained by altitude. The vegetation of these plots was not subject to burning or felling in the last 22 years, since 1996, the creation date of the NRRCL. A more detailed description of the soil and vegetation of the plots can be found in Bown et al. (2014).

\section{Matorral types}

To have a better description of the species diversity and composition of the matorral across the 12 plots, we classified the matorral into three types: a) Cryptocarya alba (Lauraceae) and Quillaja saponaria (Quillajaceae) woodlands (Ca-Qs, six plots); b) Q. saponaria and Lithraea caustica (Anacardaceae) shrublands (Qs-Lc, three plots); and, c) Acacia caven (Fabaceae) and Trevoa quinquenervia (Rhamnaceae) scrublands (Ac-Tq, three plots) (Fig. 2). This classification was performed according to the floristic dissimilarity among plots through cluster analysis. The floristic dissimilarity was calculated on the basis of the Bray and Curtis index using the relative proportion of basal area among species (Additional file 1: Online Resource 1). The cluster was carried out through the hierarchical average method. Data analysis was performed in $R$ version 3.4.0 ( $R$ Core Team 2017). We used the package "vegan" for this analysis (Oksanen et al. 2017).

\section{Abiotic and biotic variables measurements}

In line with each hypothesis, we calculated in total 19 abiotic and biotic variables at the plot level (Table 1).

\section{Vegetation quantity measurements}

In 2010, tree density (TD), tree basal area (BA) and leaf area index of shrubs and trees (LAI) were measured as surrogates of vegetation quantity. $\mathrm{TD}$ and $\mathrm{BA}$ were quantified with trees having one or more stems alive with a $\mathrm{DBH} \geq 5 \mathrm{~cm}$ (this criterion included species with multistemmed individuals). The leaf area was estimated with an AccuPAR/LAI ceptometer (Decagon Devices, Inc.) at $30 \mathrm{~cm}$ above the soil level (Table 1).

\section{Functional traits measurements}

As in previous studies, we selected the plant height $(H)$ and leaf life span (LLS) as functional traits reflecting

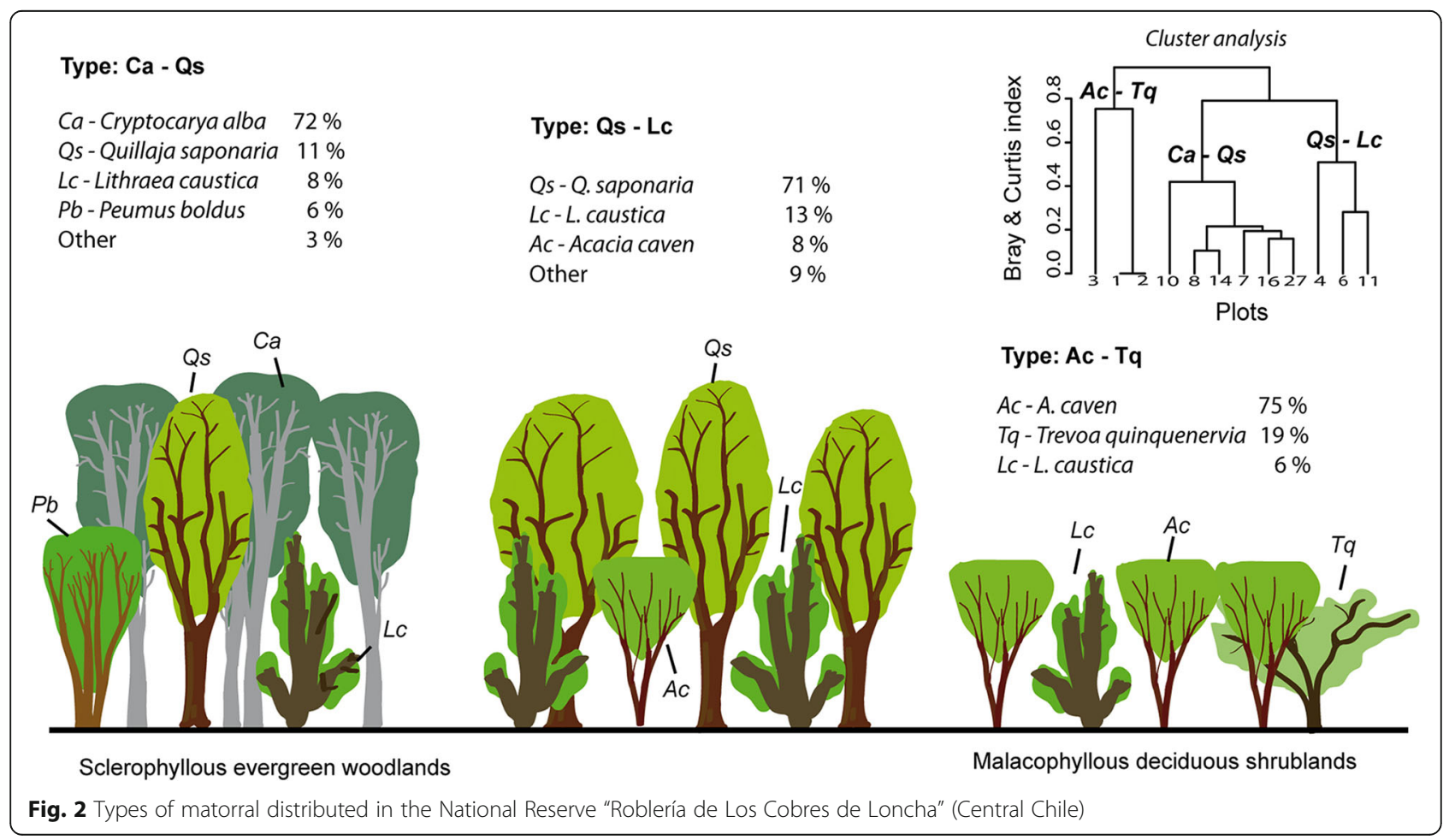


Table 1 Descriptive statistics of all biotic and abiotic independent variables used to predict aboveground biomass productivity of the Chilean matorral across the 12 plots

\begin{tabular}{|c|c|c|c|c|c|c|}
\hline Hypothesis & Variable & Abbreviation & Units & Avg & Min & Max \\
\hline \multirow[t]{3}{*}{ Vegetation quantity } & Basal area & $\mathrm{BA}$ & $\mathrm{m}^{2} \cdot \mathrm{ha}^{-1}$ & 7.16 & 0.15 & 33.33 \\
\hline & Tree density & DT & plants.ha ${ }^{-1}$ & 1949 & 48 & 4496 \\
\hline & Leaf area index & $\mathrm{LAl}$ & $\mathrm{m}^{2} \cdot \mathrm{m}^{-2}$ & 2.45 & 0.1 & 7.46 \\
\hline \multirow[t]{3}{*}{ Niche complementarity } & Tree richness & S & species.plot ${ }^{-1}$ & 3 & 1 & 5 \\
\hline & Shannon index & $H^{\prime}$ & - & 0.65 & 0 & 1.35 \\
\hline & Mean pairwise distance & MPD & - & 0.32 & 0 & 0.55 \\
\hline \multirow[t]{7}{*}{ Mass-ratio } & CWM of height plant & CWM H & $\mathrm{m}$ & 7.36 & 4.1 & 9.16 \\
\hline & CWM of leaf life span & CWM LLS & months & 24 & 10 & 40 \\
\hline & Species dominance $\left(p_{i}\right)^{*}$ & & & & & \\
\hline & Cryptocarya alba & C. alba & proportion & 0.27 & 0 & 0.92 \\
\hline & Peumus boldus & P. boldus & proportion & 0.01 & 0 & 0.10 \\
\hline & Lithraea caustica & L. caustica & proportion & 0.09 & 0 & 0.24 \\
\hline & Quillaja saponaria & Q. saponaria & proportion & 0.20 & 0 & 1 \\
\hline \multirow[t]{7}{*}{ Soil resources availability } & Volumetric water content & WW & $\mathrm{m}^{3} \cdot \mathrm{m}^{-3}$ & 0.12 & 0.17 & 0.25 \\
\hline & Soil nitrogen content & $\mathrm{N}$ & $\%$ & 0.18 & 0.06 & 0.34 \\
\hline & Soil inorganic nitrogen & SIN & ppm & 11 & 8.2 & 23 \\
\hline & Carbon/nitrogen ratio & $\mathrm{C} / \mathrm{N}$ & ratio & 14.18 & 10.52 & 19.11 \\
\hline & Clay & CY & $\%$ & 11.74 & 2.9 & 22.1 \\
\hline & Silt & ST & $\%$ & 32.5 & 18.0 & 50.6 \\
\hline & Sand & SD & $\%$ & 55.81 & 34.9 & 79.1 \\
\hline
\end{tabular}

Legend: $\left(^{*}\right)$ The averages were computed across all the plots. $p_{i}=$ species relative abundances in basal area. CWM $=$ Community-Weighted Mean. MPD $=$ Mean species pairwise dissimilarity. Average (Avg), minimum value (Min) and maximum value (Max)

different strategies to use carbon/water among plant species (Paquette and Messier 2011; Ruiz-Benito et al. 2014). The $H$ was measured as the shortest distance between the upper crown and the ground level, expressed in meters (Pérez-Harguindeguy et al. 2013). The mean value of $H$ for each species was obtained measuring trees $\mathrm{DBH} \geq 5 \mathrm{~cm}$ of $\mathrm{DBH}$ across the 12 plots covering all species (292 trees were measured). The $H$ was estimated with a clinometer PM 5/360 (SUUNTO, Finland). The LLS was obtained from the literature (Montenegro et al. 1982b; Specht 1988). This functional trait was defined as the time period during which an individual leaf is alive and physiologically active, and expressed in months (Pérez-Harguindeguy et al. 2013).

\section{Measuring species and functional diversity}

As in previous studies, species richness $(S)$, ShannonWiener index $\left(H^{\prime}\right)$ (Zhang et al. 2012) and the mean species pairwise dissimilarity (MPD) (de Bello et al. 2016) were calculated as surrogates of niche complementarity (Table 1 ). $S$ represented the number of different species within a plot. $H^{\prime}$ was calculated following the equation:

$$
H^{\prime}=-\sum_{i=1}^{S} \log _{2}\left(p_{i} p_{i}\right)
$$

where $H^{\prime}$ is a metric of community diversity, by taking into account the number $(S)$ and the distribution of the species relative abundance $\left(p_{i}\right)$ - which was calculated through the ratio between the basal area of each species and the total basal area per plot.

MPD was computed following the equation (de Bello et al. 2016):

$$
\mathrm{MPD}=\frac{1}{\sum_{i>j}^{S}\left(p_{i} p_{j}\right)} \sum_{1>j}^{S}\left(d_{i j} p_{i} p_{j}\right)
$$

where, $S$ is the species richness in a community and, $d_{i j}$ is the distance between pairwise species $i$ and $j$. The $p_{i}$ and $p_{j}$ are the relative abundances of species $i$ and $j$, respectively. The $d_{i j}$ was calculated with the Gower distance using species' traits, such as plant height $(H)$ and leaf life spans (LLS). The relative species abundances were based on the basal area (Additional file 1: Online Resource 1).

\section{Measuring species and functional dominance}

In line with Conti and Diaz (2013) the relative abundance $\left(p_{i}\right)$ of two late-successional sclerophyllous $(C$. 
alba and $P$. boldus) and two early-successional sclerophyllous (L. caustica and Q. saponaria) (Armesto et al. 1994) were quantified with the relative basal area of the corresponding species. These four species were those most dominant and frequent across the plots (Additional file 1: Online Resource 1).

Additionally, the community-weighted mean trait value $(\mathrm{CWM})$ was calculated using the species mean values of plant height $(H)$ and leaf life span (LLS) and the relative abundances through the following equation (Garnier et al. 2004):

$$
\mathrm{CWM}=\sum_{i=1}^{S}\left(r_{i} p_{i}\right)
$$

where, $S=$ number of species in the community; $r_{i}=$ value of the functional trait of the $i^{\text {th }}$ species; and $p_{i}=$ relative abundance of the $i^{\text {th }}$ species, calculated as the relative basal area of the species.

\section{Soil resources measurements}

Spatial differences of soil resource availability were measured through the soil volumetric water content (VWC), total nitrogen $(\mathrm{N})$, carbon-nitrogen ratio $(\mathrm{C} / \mathrm{N})$, soil inorganic nitrogen in the form of ammonium and nitrate (SIN) and soil texture (sandy, lime, clay) (Table 1). The VWC in each plot was obtained in winter and spring of 2009 and summer and autumn of 2010. In each season three soil samples were taken per plot using a soil corer (a metal cylinder of $5 \mathrm{~cm}$ in diameter and $30 \mathrm{~cm}$ in length). The VWC $\left(\mathrm{m}^{3} \mathrm{H}_{2} \mathrm{O}\right.$ per $\mathrm{m}^{3}$ soil) was calculated as the gravimetric water content $\left(\Theta_{\mathrm{g}}\right)$ multiplied by the soil bulk density $\left(\rho_{\mathrm{b}}\right)$ according to the following equation (Silva et al. 2000):

$\mathrm{VWC}=\rho_{\mathrm{b}} \Theta_{\mathrm{g}}(4)$

The soil bulk density was calculated by the wax paraffin method with aggregate samples taken from 10 to $40 \mathrm{~cm}$ deep (Gómez-Giraldo 2013).

The soil $\mathrm{N}$ and total soil carbon $(\mathrm{C})$ were obtained for each plot taking three sample from 0 to $30 \mathrm{~cm}$ in soil depth the year 2012. The $\mathrm{C} / \mathrm{N}$ ratio was used as a proxy of the nitrogen released by microbial decomposition. Higher $\mathrm{C} / \mathrm{N}$ ratios (low nitrogen) reduces mineralization rates, since micro-organism requieres nitrogen for growth, while lower $\mathrm{C} / \mathrm{N}$ ratios increase the mineralization proccess due to nitrogen surpassing micro-organism requirements for growth, and thus nitrogen become avaible to plants (Chapin et al. 2014). For this reason, $\mathrm{C} / \mathrm{N}$ ratios have an inverse relation with forest productivity (Yamakura and Sahunalu 1990). Total soil $C$ and $N$ were determined using a CNS analyzer at the Soils and Foliage Analyses Laboratory, Universidad Católica de Chile, Santiago, Chile.

SIN was obtained at the plot level by adding ammonium $\left(\mathrm{NH}_{4}^{+}\right)$and nitrate $\left(\mathrm{NO}_{3}^{-}\right)$chemical extractions. Four soil samples taken at $0-30 \mathrm{~cm}$ in soil depth were randomly cored from each plot, placing $10 \mathrm{~g}$ of fresh soil from each sample in $50 \mathrm{~mL} 2 \mathrm{~mol} \cdot \mathrm{L}^{-1} \mathrm{KCl}$. Soil extracts were shaken for two hours to elucidate ions from the soil to the $\mathrm{KCl}$ solution. Then, soil extracts were left to settle for half an hour before they were filtered using Whatman $\mathrm{N}^{\circ} 1$ filter paper. Ammonium and nitrate concentration were determined using the Kjeldahl steam distillation method (Bremner 1965). The SIN was sampled in winter and spring of 2009 and summer and autumn of 2010. The measurements were averaged for the year. Our measurement of SIN was a surrogate of nitrogen availability to plants released by microbial activity in a year (Gray and Schlesinger 1981).

Soil texture data was obtained from a previous research carried out in the same 12 plots used in this study during 2012 (Nangari-Piña 2012). That study estimated silt, clay and sand fractions from 0 to $50 \mathrm{~cm}$ in depth. Soil texture was included in the analysis as it is a key component driving soil resource availability (Noy-Meir 1973). For instance, sandy soils may increase AGBP in ecosystems limited by water, enhancing water infiltration, water storage to greater soil depths avoiding evaporation (Sala et al. 1988), and facilitating root growth to deeper layers (van der Sande et al. 2017a).

\section{Estimating forest above-ground biomass productivity}

At the plot level, above-ground biomass productivity (AGBP) was calculated as the difference in aboveground biomass (AGB) of all the living trees in the summer of $2010\left(t_{o}\right)$ versus those alive in the spring of 2017 $\left(t_{f}\right)$ following the equation proposed by Prado-Junior et al. (2016):

$$
\mathrm{AGBP}=\left(\mathrm{AGB}_{\mathrm{f}}-\mathrm{AGB}_{\mathrm{o}}\right) /\left(\mathrm{t}_{\mathrm{f}}-\mathrm{t}_{\mathrm{o}}\right)
$$

$\mathrm{AGBP}=$ Above - ground biomass productivity of surviving trees between $t_{f}$ and $t_{o}\left(\mathrm{~kg} \cdot \mathrm{m}^{-2} \cdot\right.$ year $\left.^{-1}\right)$,

$\mathrm{AGB}_{\mathrm{o}}=$ Above - ground biomass of trees alive in $\mathrm{t}_{\mathrm{o}}\left(\mathrm{kg} \cdot \mathrm{m}^{-2}\right)$,

$\mathrm{AGB}_{\mathrm{f}}=$ Above - ground biomass of trees alive in $\mathrm{t}_{\mathrm{f}}\left(\mathrm{kg} \cdot \mathrm{m}^{-2}\right)$,

$t_{f}-t_{o}=$ Interval of time (years).

AGB was estimated adding the biomass of all the trees alive with a $D B H \geq 5 \mathrm{~cm}$. The lack of species-specific models to estimate AGB in the Chilean matorral led us to use the following general allometric equation (Chave et al. 2005):

$$
\begin{aligned}
\mathrm{AGB}=\rho \times \exp (-0.667 & +1.784 \ln (\mathrm{DBH})+0.0207(\ln (\mathrm{DBH}))^{2} \\
& \left.-0.0281(\ln (\mathrm{DBH}))^{3}\right)
\end{aligned}
$$

$\mathrm{AGB}=$ Aboveground biomass $(\mathrm{kg})$, $\rho=$ Stem wood density $\left(\mathrm{g} \cdot \mathrm{cm}^{-3}\right)$, $\mathrm{DBH}=$ Diameter at breast height $(\mathrm{cm})$. 
The $\rho$ of the nine dominant species was obtained from branch stem samples collected from 10 mature trees by species during the spring of 2016, following standardized protocols (Pérez-Harguindeguy et al. 2013) (Additional file 1: Online Resource 2).

\section{Data analysis}

We analyzed the effects of the independent variables on AGBP through linear regressions, having as reference the sequential procedure proposed by Díaz et al. (2007). A pairwise linear regression analysis was performed to test the effect of each independent variable on aboveground biomass productivity (AGBP). Prior to this analysis, linear and nonlinear relationships of each independent variable with AGBP were checked. Nonlinear (as logarithmic, potential and exponential relationships) were analyzed through simple linearized regressions using logarithmic transformations. If the nonlinear models were marginally better in predicting AGBP, then for purposes of parsimony, simpler linear models were used (Additional file 1: Online Resource 3). Then, the best predictors into each mechanism explaining the AGBP were identified through a backward elimination procedure. These best predictors were introduced in a global linear regression model and then we derived a set of models with all the possible combinations, after which were ranked based on Akaike's information criterion for small samples (AICc) (Anderson 2008). The AICc differences $(\Delta s)$ between the best model and any other model were used to rank them from best to worst. The Akaike's weight $(w)$ was derived for each model to describe the probability that a given model is the best in a scale from 0 to 1 (Burnham and Anderson 2011). The best subset of models was selected using a confidence of $95 \%$ (those models whose cumulative Akaike weight, $w_{i}, \leq 0.95$ ) (Symonds and Moussalli 2011). Collinearity among predictors was assessed in the best subset of models with the variance inflation factor (VIF). Those models having a VIF $<10$ were maintained in the best subset (Zuur et al. 2010). Then, the best subset was averaged calculating a weighted averaged of the partial coefficients $(\beta)$ and the relative importance (RI) of predictors (probability that a given predictor is involved in the best model). All the data analysis was performed in the $\mathrm{R}$ system for statistical computing version 3.4.0 (R Core Team 2017). The species and functional diversity indices were calculated using the "vegan" package (Oksanen 2011). The CWM was calculated using the "FD" package (Laliberte and Legendre 2010). The package "MuMIn" was used for calculating the AICc and multimodel inference approach (Barton 2018).

\section{Results}

Aboveground biomass productivity (AGBP) was on average of $0.14 \mathrm{~kg} \cdot \mathrm{m}^{-2} \cdot$ year $^{-1}$. Generally, AGBP increased from malacophyllous deciduous shrublands to evergreen sclerophyllous woodlands ranging from 0 to $0.42 \mathrm{~kg} \cdot \mathrm{m}^{-}$ ${ }^{2}$ year $^{-1}$. The values of AGBP were positive in almost all the plots, but in two plots dominated by Q. saponaria and $L$. caustica the growth was nil. The analysis of simple pairwise regression suggested that AGBP significantly increased with increasing vegetation quantity (tree density, basal area, leaf area index) (Fig. 3a-c), species and functional dominance (relative abundance of C. alba and P. boldus, CWM of plant height and CWM of leaf life span) (Fig. $3 \mathrm{~d}-\mathrm{g}$ ) and some soil attributes related to resources availability (sand \%, volumentric water content, soil nitrogen content) (Fig. $3 \mathrm{~h}-\mathrm{j})$. However, some variables related to species dominance (relative dominance of Q. saponaria and L. caustica) (Additional file 1: Online Resource 4), soil resources availability (SIN, C/N) (Fig. 3k-l) and all the variables related to niche complementarity ( $S, H^{\prime}, \mathrm{MPD}$ ) (Fig. $3 \mathrm{~m}-\mathrm{o}$ ) did not show any significant effect on AGBP. Further details about the simple linear regressions fitted can be found in Additional file 1: Online Resource 4.

The backward elimination procedure allowed identifying the best predictors driving AGBP into each subset of hypotheses. Such predictors were the following: tree density (hypothesis of vegetation quantity), relative abundance of $C$. alba (hypothesis of dominance), sand fraction (hypothesis of resources availability); and species richness and Shannon index (niche complementarity) (Additional file 1: Online Resource 5). These key predictors were also correlated to other variables linked to the same hypothesis (evaluated through the Pearson correlation coefficient). For instance, tree density was a variable closely related to BA $(r=0.82 ; P<0.001)$ and LAI $(r=0.82 ; P<0.01)$. The relative abundance of $C$. alba had a positive correlation with the relative abundance of $P$. boldus $(r=0.67 ; P=0.02), \mathrm{CWM}$ of $H(r=0.73 ; P=$ $0.01)$ and CWM of LLS $(r=0.97 ; P<0.001)$. The sand \% had a positive correlation with VWC $(r=0.75 ; P=0.005)$ and $\mathrm{N}(r=0.72 ; P=0.01)$ and a negative association with the clay $(r=-0.85 ; P<0.001)$ and silt fraction $(r=-0.92$; $P<0.001)$. The $\ln (S)$ was correlated with the Shannon index $(r=0.85 ; P<0.001)$ and MPD $(r=0.94 ; P<0.001)$. See further details in Additional file 1: Online Resource 6.

The combination of these key predictors (tree density, $p_{i}$ C. alba, richness and sand) yielded 16 candidate linear regression models - which were ranked and compared through the AICc multi-model inference procedure. This analysis showed that there was not an exclusive best model explaining AGBP. The predictors from all mechanisms hypothesized were included in the best subset of linear regression models (six models) with a confidence $>95 \%$. All these models combining two predictors had acceptable collinearity (VIF $<10)$. The best models had tree density (vegetation quantity hypothesis) and/or 


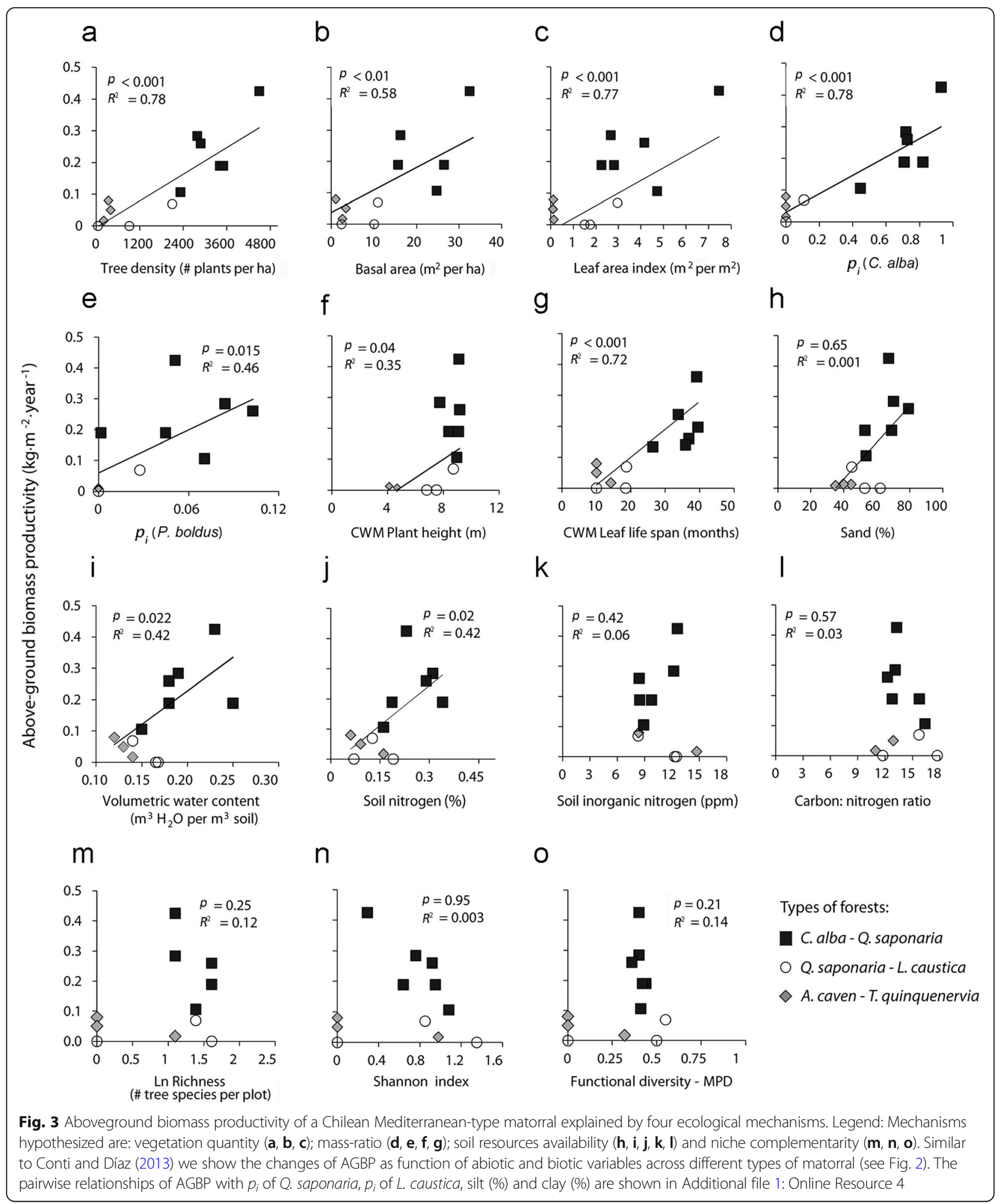

the relative dominance of $C$. alba (mass-ratio hypothesis) as common predictors having positive effect on AGBP. The models that included either $S$ (niche complementarity) or sand (\%) (resource availability) were less commons. Furthermore, $S$ had negative effects on AGBP (Table 2).

The averaging model procedure showed that tree density was the strongest predictor increasing AGBP 
$(\beta=0.76$; Importance $=0.69)$ followed by the relative abundance of $C$. alba $(\beta=0.30$; Importance $=0.36)$. In contrast, species richness had a small effect decreasing AGBP $(\beta=-0.15$; Importance $=0.44)$ and, the sand $(\%)$ had the smallest positive effect on AGBP $(\beta=0.006$; Importance $=0.04)($ Table 3$)$.

The analysis showed that vegetation quantity and massratio were the key mechanisms favoring matorral AGBP. In contrast, soil resources availability and niche complementarity were unlikely to largely increase AGBP.

\section{Discussion}

The above-ground biomass productivity (AGBP) found in this study is within the range for mediterranean-type forests $\left(0.12\right.$ to $0.65 \mathrm{~kg} \cdot \mathrm{m}^{-2} \cdot$ year $^{-1}$ ) (Ehleringer and Mooney 1983; Chapin et al. 2014). However, some matorral plots showed lower or null AGBP. Such marginal response might be due to recurring drought events from 2010 to 2015 in central Chile (Garreaud et al. 2017).

Vegetation quantity and conservative species drive AGBP Tree above-ground biomass productivity (AGBP) increased mainly by vegetation quantity, and dominance of species rather than by soil resources availability and niche complementarity, from deciduous malacophyllous shrublands to evergreen sclerophyllous woodlands. This finding agrees with studies in tropical and temperate forests showing that vegetation quantity (Paquette and Messier 2011; Lohbeck et al. 2015; Ojha and Dimov 2017) and dominance of particular species were more important for AGBP than other mechanisms (Finegan et al. 2015; Prado-Junior et al. 2016). Furthermore, our findings seem to contradict those from mediterraneantype forests of Spain (Troumbis and Memtsas 2000; Vilà et al. 2003) and California (Rundel 1982), where species diversity and nutrients are key drivers of productivity, respectively.

A greater vegetation quantity may increase AGBP by increasing the efficiency for capturing solar energy (Reich 2012) and reducing stressful micro-environmental conditions. Previous studies suggested that higher tree density in the Mediterranean Basin - type matorral had a positive relationship with carbon uptake (Vilà et al. 2013). It is possible that higher tree density and leaf area increase shading, which in turn, reduce the evaporation from the soil, and mitochondrial respiration to sustain growth and repair damages due to high radiative stresses (Holmgren et al. 1997).

The species dominance may increase AGBP because some particular tree species, such as C. alba and P. boldus (evergreen sclerophyllous) increased the CWM of $H$ and the CWM of LLS (all these variables were correlated) favoring the accumulation of greater vegetation quantity and longer periods intercepting light and assimilating carbon in the canopy of the matorral (Ehleringer and Mooney 1977; Rundel 1982). In contrast, deciduous malacophyllous have a smaller plant height and shorter period of growth, which might reduce AGBP (Mooney 1977; Montenegro 1982).

Vegetation quantity and dominance of taller species with a conservative leaf strategy to use carbon (such as $C$. alba) were pivotal/complementary mechanisms driving

Table 2 Best subset of models explaining aboveground biomass productivity (AGBP)

\begin{tabular}{|c|c|c|c|c|c|c|c|c|}
\hline $\mathrm{H}$ & Models & Predictor variables & $P$ & VIF & $R_{\text {Adj }}^{2}$ & $\mathrm{AlCC}$ & $\Delta \mathrm{s}$ & $w$ \\
\hline \multirow[t]{3}{*}{$\mathrm{V}-\mathrm{N}$} & \multirow[t]{3}{*}{$\mathrm{AGBP}=1.1 \mathrm{TD}-0.4 \ln (S)$} & Model & $<0.001$ & & \multirow[t]{3}{*}{0.83} & \multirow[t]{3}{*}{22.7} & \multirow[t]{3}{*}{0} & \multirow[t]{3}{*}{0.38} \\
\hline & & $\mathrm{TD}$ & $<0.001$ & 1.7 & & & & \\
\hline & & $\ln (S)$ & 0.04 & 1.7 & & & & \\
\hline M & $\mathrm{AGBP}=0.88 p_{i} \mathrm{C} . \mathrm{alba}$ & Model & $<0.001$ & - & 0.76 & 23.5 & 0.7 & 0.26 \\
\hline V & $\mathrm{AGBP}=0.88 \mathrm{TD}$ & Model & $<0.001$ & - & 0.76 & 23.8 & 1 & 0.23 \\
\hline \multirow[t]{3}{*}{$\mathrm{M}-\mathrm{N}$} & \multirow[t]{3}{*}{$\mathrm{AGBP}=0.9 p_{i} C$. alba $-0.2 \ln (S)$} & Model & $<0.001$ & & \multirow[t]{3}{*}{0.77} & \multirow[t]{3}{*}{26.6} & \multirow[t]{3}{*}{3.8} & \multirow[t]{3}{*}{0.06} \\
\hline & & $p_{i}$ C. alba & $<0.001$ & 1.45 & & & & \\
\hline & & $\ln (S)$ & 0.27 & 1.45 & & & & \\
\hline \multirow[t]{3}{*}{$M-V$} & \multirow[t]{3}{*}{$\mathrm{AGBP}=0.5 p_{i} \mathrm{C} . a^{\prime} b a+0.4 \mathrm{TD}$} & Model & $<0.001$ & & \multirow[t]{3}{*}{0.76} & \multirow[t]{3}{*}{27.2} & \multirow[t]{3}{*}{4.4} & \multirow[t]{3}{*}{0.04} \\
\hline & & $p_{i} C$. alba & 0.34 & 10 & & & & \\
\hline & & TD & 0.38 & 10 & & & & \\
\hline \multirow[t]{3}{*}{$M-R$} & \multirow[t]{3}{*}{$\mathrm{AGBP}=0.77 \mathrm{TD}+0.17 \mathrm{SD}$} & Model & 0.001 & & \multirow[t]{3}{*}{0.75} & \multirow[t]{3}{*}{27.5} & \multirow[t]{3}{*}{4.7} & \multirow[t]{3}{*}{0.04} \\
\hline & & TD & 0.04 & 6.1 & & & & \\
\hline & & SD & 0.97 & 6.1 & & & & \\
\hline
\end{tabular}

Legend: Hypotheses $(H)$ tested, $V$ Vegetation quantity; $M$ Mass-ratio, $N$ Niche complementarity, $R$ Resources availability. Predictors, TD Tree density, $p_{i}$ species relative abundance, $S$ Species richness, $H^{\prime}$ Shannon index, $S D$ Sand $(\%) ; R_{\text {Adj }}^{2}$ adjusted determination coefficient. All multiple regression models were statistically significant $(P<0.05)$. The following acronyms were used: VIF = Variance inflation factor; AICc $=$ Akaike's information criterion for small samples $(\mathrm{AIC}) . \Delta s=$ Difference among AICC of any model respect to the best. $w=$ Akaike's weight, it is the probability of a model to be the best in scale from 0 to 1 
Table 3 Averaging model procedure showing standardized coefficients $(\beta)$ and relative importance (RI) of predictors influencing AGBP

\begin{tabular}{llll}
\hline Hypothesis & Predictors & $\beta$ & $\mathrm{Rl}$ \\
\hline Vegetation quantity & Tree density & 0.76 & 0.69 \\
Mass-ratio & $p_{i}$ C. alba & 0.30 & 0.36 \\
Niche complementarity & In (Species richness) & -0.15 & 0.44 \\
Resources availability & Sand (\%) & 0.006 & 0.04 \\
\hline
\end{tabular}

AGBP in our study and also in other ecosystems under harsh environmental conditions (Paquette and Messier 2011; Vilà et al. 2013; Prado-Junior et al. 2016). However, under more favorable environmental conditions, such as in humid tropical forests, AGBP was both related negatively to vegetation quantity and positively to taller dominant species with acquisitive strategies to use carbon (< CWM LLS) (Finegan et al. 2015; van der Sande et al. 2017b). Possibly, a greater accumulation of biomass and the dominance of particular species might be the best suit of attributes to grow in a community under harsh environmental stresses.

\section{Soil resources availability have less importance for productivity}

In line with previous studies carried out in semiarid ecosystems, we found that the sand fraction, the soil water content and soil nitrogen had a significant positive effect on AGBP of the matorral (Kummerow et al. 1982; Sala et al. 1988). A greater sand fraction might increase AGBP due to greater water infiltration and less evaporation (Sala et al. 1988), longer periods for releasing soil nitrogen by micro-organisms (Schwinning and Sala 2004), and root growth to deeper soil layers (van der Sande et al. 2017a). However, this study was unable to demonstrate that these soil variables would better explain AGBP than vegetation quantity and species dominance. Some studies suggested that AGBP is scarcely driven by spatial differences in soil resources, since dominant species may exhibit particular adaptative traits allowing them to develop under semi-arid and infertile conditions (Prado-Junior et al. 2016). For instance, evergreen sclerophyllous species have developed strategies to conserve water by reducing stomatal and mesophyll conductance (Giliberto and Stay 1978; Canadell and Zeedler 1995). Besides, evergreen sclerophyllous species may develop deep roots to capture water throughout the year independently of the water content in the topsoil (Hoffmann and Kummerow 1978). Likewise, it has been shown that the growth of sclerophyllous species can be marginally influenced by soil nutrients availability (Rundel 1982; Espinoza et al. 2017). Some malacophyllous deciduous species (Rhamnaceae and Fabaceae) are N-fixers (Rundel 1982), which might increase AGBP. However, in semi-arid ecosystems, nitrogen soil availability depends upon soil water (Schwinning and Sala 2004), which is scarce in matorrals dominated by these species.

Furthermore, the SIN and $\mathrm{C} / \mathrm{N}$ ratio in our study were unrelated to productivity, possibly because the nitrogen released by microbial activity in mediterraneanecosystems is scarce, since stressful environmental conditions and recalcitrant soil organic matter are limiting decomposition and nutrient release (Gray and Schlesinger 1981).

\section{Negative effect of niche complementarity on productivity} In contrast to evidence showed by previous studies (Zhang et al. 2012; Liang et al. 2016) this study shows that either species diversity (richness and Shannon index) or functional diversity might not increase the matorral AGBP. In some studies, species richness had a positive effect on forest AGBP in parallel to vegetation quantity and dominance predictors (Ruiz-Jaen and Potvin 2010; Paquette and Messier 2011; Vilà et al. 2013). However, in this study species richness, which is correlated with evenness and functional diversity, had consistently a negative effect on AGBP, as in some previous studies (Finegan et al. 2015; Prado-Junior et al. 2016). It is possible that species diversity is only the result of disturbances promoting the establishment of a higher number of species rather than the result of complementary resource use (Grime 2006). Thus, a moderate disturbance of the matorral could increase species diversity (Rundel 1981), but in parallel could affect the competitive ability and plant density of dominant species, which are the potential drivers of AGBP.

\section{Limitations}

Overall, observational studies in natural ecosystems have inherent problems for testing causal relationships, as a result that abiotic and biotic variables while being correlated are influencing simultaneously ecological processes such as AGBP. However, multiple linear regression and model selection procedures might contribute to separate individual effects and assess such relationships (Díaz et al. 2007). Furthermore, we aware that our sample size is relatively small and we have collinearity among most of the independent variables, which might reduce the power of our inferences by increasing the probability to commit a type II error (i.e. failure to reject the null hypothesis when it is untrue) (Zuur 2010). However, despite these potential sources of error we were able to detect significant relationships among AGBP and most of the independent variables, which gave us chance to test all the hypotheses proposed. There were previous studies, with similar limitations, in which there was also possible to find significant effects of variables related to biodiversity on ecological process through linear 
regression models (Conti and Diaz et al. 2013; Lohbeck et al. 2015).

Besides, there might be a potential unexplained variation in our results due to geographic and climatic differences among plots, although as the spatial extent of our study was relatively small such variation was probably small and randomly allocated within the plots.

\section{Conclusions}

The findings of this study suggest that vegetation quantity and species dominance with greater plant height and a conservative strategy to use carbon are pivotal drivers for productivity. The importance of both mechanisms suggests that canopy quantity and quality may be key to sustain AGBP and linked ecosystem services in the mediterranean-type matorral, since these dominant species mediate greater biomass gains and assimilating carbon continuously during the year. In contrast, taxonomic species diversity, functional diversity and soil resources might be less important to drive AGBP, at least at this small scale of observation. Possibly, strong competition for resources avoids maximizing species diversity in the highly productive matorral, while topsoil resources are not a factor limiting productivity, due to sclerophyllous species uptake soil resources at greater soil depths.

\section{Supplementary information}

Supplementary information accompanies this paper at https://doi.org/10. 1186/s40663-019-0205-z.

\section{Additional file 1: Online Resource 1. Relative basal area of tree} species across 12 plots in the National Reserve Roblería de los Cobres de Loncha (Chile). Online Resource 2. Wood density of nine tree species of the Chilean mediterranean-type matorral. Online Resource 3. Analyzing linear and nonlinear relationships of biotic and abiotic variables with AGBP. Online Resource 4. Simple pairwise linear regressions analyzing the effect of species diversity, vegetation quantity, species relative abundance and soil resources availability on above-ground biomass productivity of the mediterranean-type matorral of Chile. Online Resource 5. Backward elimination procedure for selecting variables explaining aboveground biomass through multiple linear regressions. Online Resources 6. Pairwise correlation matrix among independent variables.

\section{Abbreviations \\ AGB: Above-ground biomass; AGBP: Above-ground biomass productivity; AICc: Akaike's information criterion for small samples; BA: Basal area; C/ N: Carbon-nitrogen ratio; CWM: Community Weight Median; CY: Clay; DBH: Diameter at breast height; ER: Evidence ratio; $H$ : Plant height; $H$ ': Shannon index; LAI: Leaf area index; LLS: Leaf life span; MPD: Mean Pairwise Distance; N: Total soil nitrogen; NRRCL: National Reserve Roblería de Los Cobres de Loncha; $p_{i}$ : Relative abundance of species; S: Species richness; SD: Sand; SIN: Soil inorganic nitrogen; ST: silt; TD: Tree density; \\ WW: Volumetric water content; w: Akaike's weight; $\rho$ : Stem wood density}

\section{Acknowledgments}

We appreciate the collaboration of Roberto Cerda, park ranger, of the CONAF (National Forestry Corporation) for their help during the fieldwork in the National Reserve of "Roblería de Los Cobres de Loncha". Besides, we thank Juan Pablo Fuentes (Universidad de Chile) for his collaboration recollecting and analyzing soil samples from all the plots of this study. Also, we thank Lucas Enrico (Universidad Nacional de Córdoba, Argentina) for his valuable suggestions for this paper.

\section{Authors' contributions}

$A A$ and $H B$ read and approved the final manuscript. $A A$ conceived the presented idea and developed the theory and analytical methods. AA and $\mathrm{HB}$ planned and carried out the measurements. AA and HB discussed the methodologies and results. AA wrote the manuscript with assistance from HB. Both authors read and approved the final manuscript.

\section{Funding}

Funding for this research was obtained from CONICyT (Comisión Nacional de Investigación Científica y Tecnológica) for the grant Fondecyt No 1150877. Additional funding was derived from the CONICYT doctoral grant No 21150802

\section{Availability of data and materials}

The datasets used and/or analyzed during the current study are available from the corresponding author on reasonable request.

\section{Ethics approval and consent to participate}

Not applicable.

\section{Consent for publication}

Not applicable.

\section{Competing interests}

The authors declare that they have no competing interests.

Received: 31 January 2019 Accepted: 15 October 2019

Published online: 06 November 2019

\section{References}

Amigo J, Ramírez C (1998) A bioclimatic classification of Chile: woodland communities in the temperate zone. Plant Ecol 136:9-26. https://doi.org/10. 1023/A:1009714201917

Anderson D (2008) Model based inference in the life sciences: a primer on evidence. Springer, New York

Armesto J, Martínez J (1978) Relations between vegetation structure and slope aspect in the mediterranean region of Chile. J Ecol 66:881-889

Armesto J, Vidiella P, Jiménez H (1994) Evaluating causes and mechanisms of succession in the mediterranean region in Chile and California. In: Arroyo MT, Zedler PH, Fox M (eds) Ecology and biogeography of mediterranean ecosystems in Chile, California and Australia. Springer, New York

Barton K (2018) MuMln: Multi-Model inference. R package version 1(42):1 https:// CRAN.R-project.org/package $=$ MuMln.

Bown H, Fuentes JP, Perez-Quezada JF, Franck N (2014) Soil respiration across a disturbance gradient in sclerophyllous ecosystems in Central Chile. Cienc Investig Agrar 41:89-106. https://doi.org/10.4067/S0718-16202014000100009

Bremner J (1965) Inorganic forms of nitrogen. In: Black C, Evans DD, White J, Ensminger LE, Clark F (eds) Methods of soil analysis: part 2, chemical and microbiological properties. American Society of Agronomy, Wisconsin

Burnham K, Anderson D, Huyvaert K (2011) AIC model selection and multimodel inference in behavioral ecology: some background, observations, and comparisons. Behav Ecol Sociobiol 65:23-35. https://doi.org/10.1007/s00265010-1029-6

Campo J, Vázquez-Yánes C (2004) Effects of nutrient limitation on aboveground carbon dynamics during tropical dry forest regeneration in Yucatán, México. Ecosystems 7:311-319. https://doi.org/10.1007/s10021-003-0249-2

Canadell J, Zedler PH (1995) Underground structures of woody plants in Mediterranean ecosystems of Australia, California and Chile. In: Arroyo MT, Zedler PH, Fox M (eds) Ecology and biogeography of Mediterranean ecosystems in Chile, California and Australia. Springer, New York

Chapin FS, Matson P, Vitousek P (2014) Principles of terrestrial ecosystem ecology, 2nd edn. Springer, New York

Chapin FS, Walker B, Hobbs R, Hooper DU, Lawton JH, Sala OE, Tilman D (1997) Biotic control over the functioning of ecosystems. Science 277:500-504. https://doi.org/10.1126/science.277.5325.500

Chave J, Andalo C, Brown S, Cairns MA, Chambers JQ, Eamus D, Fölster H, Fromard F, Higuchi N, Kira T, Lescure JP, Nelson BW, Ogawa H, Puig H, Riera B, Yamakura T (2005) Tree allometry and improved estimation of carbon 
stocks and balance in tropical forests. Oecologia 145:87-99. https://doi.org/ 10.1007/s00442-005-0100-x

Conti G, Díaz S (2013) Plant functional diversity and carbon storage - an empirical test in semi-arid forest ecosystems. J Ecol 101:18-28. https://doi. org/10.1111/1365-2745.12012

de Bello F, Carmona CP, Lepš J, Szava-Kovats R, Pärtel M (2016) Functional diversity through the mean trait dissimilarity: resolving shortcomings with existing paradigms and algorithms. Oecologia 180:933-940. https://doi.org/ 10.1007/s00442-016-3546-0

Díaz S, Lavorel S, de Bello F, Quétier F, Grigulis K, Robson TM (2007) Incorporating plant functional diversity effects in ecosystem service assessments. PNAS 104 20684-20689. https://doi.org/10.1073/pnas.0704716104

Ehleringer J, Mooney HA (1977) Productivity of desert and Mediterranean-climate plants. In: Lange OL, Nobel PS, Osmond CB, Ziegler H (eds) Physiological plant ecology IV. Springer, New York

Espinoza SE, Santelices RE, Cabrera AM, Magni CR (2017) Interactive effects of water stress, container size and fertilizer on survival, gas exchange and morphological traits of Quillaja saponaria seedlings. Bosque 38:409-414. https://doi.org/10.4067/S0717-92002017000200018

Finegan B, Peña-Claros M, de Oliveira A, Ascarrunz N, Bret-Harte MS, CarreñoRocabado G, Casanoves F, Díaz S, Equiguren-Velepucha P, Fernandez F, Licona JC, Lorenzo L, Salgado-Negret B, Vaz M, Poorter L (2015) Does functional trait diversity predict above-ground biomass and productivity of tropical forests? Testing three alternative hypotheses. J Ecol 103:191-201. https://doi.org/10.1111/1365-2745.12346

Fuentes ER, Montenegro G, Rundel PW, Arroyo MK, Ginocchio R, Jacksic F (1995) Functional approaches to biodiversity in the Mediterranean-type ecosystem of Central Chile. In: Davis GW, Richardson DM (eds) Mediterranean-type ecosystem. The functions of biodiversity, Springer, Berlin

Gajardo R (1994) La vegetación natural de Chile. Editorial Universitaria, Santiago

Garnier E, Cortez J, Billès G, Navas ML, Roumet C, Debussche M, Laurent G, Blanchard A, Aubry D, Bellmann A, Neill C, Toussaint JP (2004) Plant functional markers capture ecosystem properties during secondary succession. Ecology 85:2630-2637. https://doi.org/10.1890/03-0799

Garreaud R, Alvarez-Garreton C, Barichivich J, Boisier JP, Christie D, Galleguillos M, LeQuesne M, McPhee J, Zambrano-Bigiarini M (2017) The 2010-2015 mega drought in Central Chile: impacts on regional hydroclimate and vegetation. Hydrol Earth Syst Sci 21:6307-6327. https:// doi.org/10.5194/hess-21-6307-2017

Giliberto J, Estay H (1978) Water stress in some Chilean shrubs. Bot Gaz 139: $236-240$

Gómez-Giraldo JC (2013) Manual de prácticas de laboratorio de mecánica de suelos. Servicio Nacional de Aprendizaje, Tolima

Gray J, Schlesinger W (1981) Nutrient cycling in Mediterranean type ecosystems. In: Miller PC (ed) Resource use by chaparral and matorral. Springer, New York, pp 259-285

Grime JP (1998) Benefits of plant diversity to ecosystems: immediate, filter and founder effects. J Ecol 86:902-910. https://doi.org/10.1046/j.13652745.1998.00306.x

Grime JP (2006) Trait convergence and trait divergence in herbaceous plant communities: mechanisms and consequences. J Veg Sci 17:255-260. https:// doi.org/10.1111/j.1654-1103.2006.tb02444.x

Hajek ER, di Castri F (1975) Bioclimatografía de Chile. Universidad Católica de Chile, Santiago

Hoffmann A, Kummerow J (1978) Root studies in the Chilean Matorral. Oecologia 32:57-69

Holmgren M, Scheffer M, Huston M (1997) The interplay of facilitation and competition in plant communities. Ecology 78:1966-1975. https://doi.org/10. 1890/00129658(1997)078[1966:TIOFAC]2.0.CO;2

Kamruzzaman M, Ahmed S, Osawa A (2017) Biomass and net primary productivity of mangrove communities along the Oligohaline zone of Sundarbans, Bangladesh. Forest Ecosyst 4:16. https://doi.org/10.1186/s40663017-0104-0

Kummerow J, Avila G, Aljaro ME, Araya G, Montenegro G (1982) Effect of fertilizers on fine root density and shoot growth in Chilean matorral. Botanical Gazzette 143:498-504

Laliberte E, Legendre P (2010) A distance-based framework for measuring from multiple traits. Ecology 9(1):299-305. https://doi.org/10.1890/08-2244.1

Liang J, Crowther T, Picard N, Wiser S, Zhou M, Alberti G, Schulze E-D, McGuire AD, Bozzato F, Pretzsch H, De-Miguel S, Alain P, Herault B, Scherer-Lorenzen M, Barrett CB, Glick HB, Hengeveld GM, Nabuurs G, Pfautsch S, Viana H, Vibrans A,
Ammer C, Schall P, Verbyla D, Tchebakova N, Fischer M, Watson J, Chen H, Lei X, Schelhaas M, Lu H, Gianelle D, Parfenova E, Salas C, Lee E, Lee B, Kim H, Bruelheide H, Coomes D, Piotto D, Sunderland T, Schmid B, Gourlet-Fleury S, Sonke B, Tavani R, Zhu J, Brandl S, Vayreda J, Kitahara F, Searle E, Neldner V, Ngugi M, Baraloto C, Frizzera L, Baazy R, Oleksyn J, Bouriaud O, Bussotti F, Finer $L$, Jaroszewicz B, Jucker T, Valladares F, Jagodzinski A, Peri P, Gonmadje C, Marthy W, O'Brien T, Martin H, Marshall A, Rovero F, Bitariho R, Niklaus P, Alvarez-Loayza P, Chamuya N, Valencia R, Mortier F, Wortel V, Engone-Obiang N, Ferreira L, Odeke D, Vasquez R, Lewis S, Reich P (2016) Positive biodiversityproductivity relationship predominant in global forests. Science 354(6309): aaf8957. https://doi.org/10.1126/science.aaf8957

Lohbeck M, Poorter L, Martínez-Ramos M, Bongers F (2015) Biomass is the main driver of changes in ecosystem process rates during tropical forest succession. Ecology 96:1242-1252. https://doi.org/10.1890/14-0472.1.sm

Meza F, Montes C, Bravo-Martínez F, Serrano-Ortiz P, Kowalski A (2018) Soil water content effects on net ecosystem $\mathrm{CO}_{2}$ exchange and actual evapotranspiration in a Mediterranean semiarid savanna of Central Chile. Sci Rep 8:8570. https://doi.org/10.1038/s41598-018-26934-z

Montenegro G, Aljaro M, Walkowiak A, Saenger R (1982a) Seasonality, growth, and net productivity of herbs and shrubs of the Chilean Matorral. In: Conrad E, Oechel CW (eds) Proceedings of the symposium on dynamics and management of Mediterranean-type ecosystems. United States Department of Agriculture, California

Montenegro G, Aljaro ME, Walkowiak A, Saenger R (1982b) Seasonality, growth and net productivity of herbs and shrubs of the Chilean matorral. In: proceedings of the symposium on dynamics and Management of Mediterranean-Type Ecosystems. San Diego State University, California, 22-26 June 1981

Mooney HA (1977) Convergent evolution in Chile and California: Mediterranean climate ecosystems. Dowden, Hutchinson \& Ross, New York

Mooney HA, Dunn EL (1970) Convergent evolution of Mediterranean-climate evergreen sclerophyll shrubs. Evolution 24:292-303

Nangari-Piña A (2012) Variación de la actividad enzimática del suelo en formaciones vegetacionales esclerófilas de la zona central de Chile. Universidad de Chile, Dissertation

Noy-Meir I (1973) Desert ecosystems: environment and producers. Ann Rev Ecol Syst 4:25-51

Ojha S, Dimov L (2017) Linking hypothesized causal factors to aboveground biomass growth in forests of Alabama and the eastern United States. Forest Syst 26:16-29. https://doi.org/10.5424/fs/2017263-11875

Oksanen J, Guillaume-Blanchet G, Friendly M, Kindt R, Legendre P (2017) Vegan: community ecology package. https://CRAN.R-project.org/package=vegan.

Paquette A, Messier C (2011) The effect of biodiversity on tree productivity: from temperate to boreal forests. Glob Ecol Biogeogr 20:170-180. https://doi.org/ 10.1111/j.1466-8238.2010.00592.x

Pérez-Harguindeguy N, Díaz S, Garnier E, Lavorel S, Poorter H, Jaureguiberry P, Cornwell B, Craine J, Gurvich D, Urcelay C, Veneklaas EJ, Reich PB, Poorter L, Wright IJ, Ray P, Enrico L, Pausas JG, de Vos AC, Buchmann N, Funes G, Quétier F, Hodgson JG, Thompson K, Morgan HD, ter Steege H, van der Heijden MGA, Sack L, Blonder B, Poschlod P, Vaieretti MV, Conti G, Staver AC, Aquino S, Cornelissen JHC (2013) New handbook for standardized measurement of plant functional traits worldwide. Aust J Bot 61:167-234 https://doi.org/10.1071/BT12225

Poorter L, van der Sande MT, Arets M, Ascarrunz N, Enquist B, Finegan B, Licona JC, Martínez-Ramos M, Mazzei L, Meave J, Muñoz R, Nytch J, de Oliveira AA, Pérez-García EA, Prado-Junior J, Rodríguez-Velázques J, Ruschel AR, SalgadoNegret B, Schiavini I, Swenson NG, Tenorio EA, Thompson J, Toledo M, Uriarte M, van der Hout P, Zimmerman JK, Peña-Claros M (2017) Biodiversity and climate determine the functioning of Neotropical forests. Glob Ecol Biogeogr 26:1423-1434. https://doi.org/10.1111/geb.12668

Prado-Junior JA, Schiavini I, Vale VS, Arantes CS, van der Sande MT, Lohbeck M, Poorter $L$ (2016) Conservative species drive biomass productivity in tropical dry forests. J Ecol 104:817-827. https://doi.org/10.1111/1365-2745.12543

R Core Team (2017) R language and environment for statistical computing version 3. 0. 4. Vienna, Austria

Reich P (2012) Key canopy traits drive forest productivity. Proc R Soc B 279. https://doi.org/10.1098/rspb.2011.2270

Rodríguez-Soalleiro R, Eimil-Fraga C, Gomez-Garcia E, Garcia-Villabrille JD, RojoAlboreca A, Munoz F, Oliveira N, Sixto H, Perez-Cruzado C (2018) Exploring the factors affecting carbon and nutrient concentrations in tree biomass components innatural forests, forest plantations and short rotation forestry. Forest Ecosyst 5:35. https://doi.org/10.1186/s40663-018-0154-y. 
Ruiz-Benito P, Gómez-Aparicio L, Paquette A, Messier C, Kattge J, Zavala MA (2014) Diversity increases carbon storage and tree productivity in Spanish forests. Glob Ecol Biogeogr 23:311-322. https://doi.org/10.1111/geb.12126

Ruiz-Jaen M, Potvin C (2010) Tree diversity explains variation in ecosystem function in a neotropical forest in Panama. Biotropica 42(6):638-646. https:// doi.org/10.1111/j.1744-7429.2010.00631.x

Rundel PW (1981) The matorral zone of Central Chile. In: di Castri F, Goodall FD (eds) Mediterranean-type shrublands. Elsevier, New York

Rundel PW (1982) Nitrogen utilization efficiencies in Mediterranean-climate shrubs of California and Chile. Oecologia 55:409-413

Rundel PW, Arroyo MT, Cowling RM, Keeley JE, Lamont BB, Vargas P (2016) Mediterranean biomes: evolution of their vegetation, floras, and climate. Ann Rev Ecol Evol Syst 47:383-407. https://doi.org/10.1146/annurev-ecolsys$121415-032330$

Sala OE, Parton WJ, Joyce LA, Lauenroth WK (1988) Primary production of the central grassland region of the United States. Ecology 69:40-45

Schwinning S, Sala O (2004) Hierarchy of responses to resource pulses in arid and semi-arid ecosystems. Oecologia 141:211-220. https://doi.org/10.1007/ s00442-004-1520-8

Silva P, Acevedo E, Silva H (2000) Manual de estudio y ejercicios de fisiología vegetal. Universidad de Chile, Santiago

Specht RL (1988) Mediterranean-type ecosystems: a data source book. Kluwer Academic Publishers, Dordrecht

Symonds M, Moussalli A (2011) A brief guide to model selection, multimode inference and model averaging in behavioral ecology using Akaike's information criterion. Behav Ecol Sociobiol 65:13-21. https://doi.org/10.1007/ s00265-010-1037-6

Tilman D (1997) Biodiversity ecosystem functioning. In: Daily G (ed) Nature's services societal dependence on natural ecosystems. Island Press, Washington D.C

Troumbis AY, Memtsas D (2000) Observational evidence that diversity may increase productivity in Mediterranean shrublands. Oecologia 125:101-108

van der Sande M, Arets EM, Peña-Claros M, Hoobeek M, Cáceres-Siani Y, van der Hout P, Poorter L (2017b) Soil fertility and species traits, but not diversity, drive productivity and biomass stocks in a Guyanese tropical rainforest. Funct Ecol 32:461-474. https://doi.org/10.1111/1365-2435.12968

van der Sande MT, Peña-Claros M, Ascarrunz N, Arets E, Licona JC, Toledo M, Poorter $\mathrm{L}$ (2017a) Abiotic and biotic drivers of biomass change in a Neotropical forest. J Ecol 105:1223-1234. https://doi.org/10.1111/1365-2745.12756

Vilà M, Carrillo-Gavilán A, Vayreda J, Bugmann H, Fridman J, Grodzki W, Haase J, Kunstler G, Schelhaas MJ, Trasobares A (2013) Disentangling biodiversity and climatic determinants of wood production. PLoSOne. https://doi.org/10.1371/ journal.pone.0053530

Vilà M, Vayreda IJ, Comas L, Ibáñez JJ, Mata T, Obón B (2007) Species richness and wood production: a positive association in Mediterranean forests. Ecol Lett 10:241-250. https://doi.org/10.1111/j.1461-0248.2007.01016.x

Vilà M, Vayreda IJ, Gracia C, Ibáñez JJ (2003) Does tree diversity increase wood production in pine forests? Oecologia 135:299-303. https://doi.org/10.1007/ s00442-003-1182-y

Wright J, Yavitt J, Wurzburguer N, Turner B, Tanner E, Sayer E, Santiago L, Kaspari M, Hedin L, Harms K, García M, Corre M (2011) Potassium, phosphorus or nitrogen limit root allocation tree growth or litter production in a lowland tropical forest. Ecology 92:1616-1625. https://doi.org/10.1890/10-1558.1

Yamakura T, Sahunalu P (1990) Soil carbon/nitrogen ratio as a site quality index for some south-east Asian forests. J Trop Ecol 6:371-378

Zhang Y, Chen HYH, Reich PB (2012) Forest productivity increases with evenness, species richness and trait variation: a global meta-analysis. J Ecol 100:742749. https://doi.org/10.1111/j.1365-2745.2011.01944.x

Zuur AF, leno EN, Elphick CS (2010) A protocol for data exploration to avoid common statistical problems. Methods Ecol Evol 1:3-14. https://doi.org/10. 1111/j.2041-210X.2009.00001.x

\section{Submit your manuscript to a SpringerOpen ${ }^{\circ}$ journal and benefit from:}

- Convenient online submission

- Rigorous peer review

- Open access: articles freely available online

High visibility within the field

Retaining the copyright to your article

Submit your next manuscript at $\boldsymbol{\nabla}$ springeropen.com 